\title{
Seagrass epiphyte loads along a nutrient availability gradient, Florida Bay, USA
}

\author{
Thomas A. Frankovich*, James W. Fourqurean** \\ Southeast Environmental Research Program and Department of Biological Sciences, Florida International University, Miami, \\ Florida 33199, USA
}

\begin{abstract}
Total epiphyte load, epiphyte chlorophyll load, epiphyte autotrophic index, and seagrass short shoot size are compared with water column nutrient concentrations and the elemental composition of seagrass leaf tissue. The spatial patterns in these parameters are described across a nutrient availability gradient in Florida Bay, Florida, USA. Multivariate and univariate statistical analyses were performed on these parameters to test for correlations with various measures of nutrient availability. Most of the variation in Thalassia testudinum short shoot size could be described by phosphorus availability, dissolved organic matter in the water column, and water column inorganic nitrogen concentrations. Total epiphyte and epiphyte chlorophyll loads were significantly, but weakly, correlated with phosphorus availability. The measurement of total epıphyte loads and observations of epiphytic species composition along a transect adjacent to a point source of nutrients revealed that the effect of nutrient enrichment on epiphyte levels is pronounced but very localized. Epiphyte levels may not be as sensitive to moderate nutrient enrichment as other seagrass parameters (e.g. leaf tissue nutrient content).
\end{abstract}

KEY WORDS: Epiphytes - Water quality Nutrient availability - Seagrass Thalassia testudinum Florida Bay

\section{INTRODUCTION}

Seagrass meadows rank among the most productive ecosystems in nature, rivaling those of tropical rain forests and tidal marshes (Odum 1957, McRoy \& McMillan 1977, Zieman \& Wetzel 1980). Seagrass epiphytes are an important component of these highly productive ecosystems, often contributing greater than one-third to the total above ground biomass (Penhale 1977, Heijs 1984, Tomasko \& Lapointe 1991) and as much as $30 \%$ to combined seagrass/epiphyte productivity (Penhale 1977, Morgan \& Kitting 1984, Heijs $1984,1985,1987)$. Though most seagrass biomass must enter the detrital food web before it is available to higher trophic levels (Odum \& de la Cruz 1963, Fenchel 1970, Fry \& Parker 1979), epiphyte production can be a direct source of carbon available to higher trophic levels through grazing (Fry \& Parker 1979,

- Present address: Department of Environmental Sciences, University of Virginia, Charlottesville, Virginia 22903, USA

-.E-mail: frankovich@virginia edu
Kitting et al. 1984). Epiphytes may also provide a more assimilable detrital carbon source than their seagrass hosts due to the large amount of refractory structural tissue and phenolic compounds in seagrasses (Harrison 1989).

In addition to being an important component of the seagrass community, epiphytes can also be detrimental to seagrasses. Seagrasses form extensive beds in many coastal embayments worldwide, and seagrassdominated ecosystems have fared poorly in anthropogenically-influenced coastal regions because of the sensitivity of seagrasses to changes in water quality (e.g. Orth \& Moore 1983, Giesen et al. 1990, Larkum \& West 1990). The general pattern of changes in benthic vegetation accompanying eutrophication is from rooted macrophytes at low nutrient availability to domination by epiphytic and water column algae at higher levels of nutrient availability and eventually to seagrass loss during the latter stages of eutrophication (see Duarte 1995 for review). One mechanism for losses of submerged aquatic vegetation is overgrowth by epiphytes (Phillips et al. 1978, Kemp et al. 1983, Cambridge et 
al. 1986). Epiphyte loads reduce the productivity of macrophytes by shading and reducing nutrient availability (Bulthuis \& Woelkerling 1983, Twilley et al. 1985, Wetzel \& Neckles 1986, Tomasko \& Lapointe 1991, Neckles et al. 1993, 1994, Neundorfer \& Kemp 1993).

Various factors affect the distribution of epiphyte loads across both seasonal and regional scales. Structural factors, such as seagrass leaf area and seagrass leaf turnover rate, affect the space and time for epiphyte colonization and growth. Physico-chemical factors affecting epiphyte loads include nutrient availability, temperature, salinity, depth, current, and light availability and quality. Decreased seagrass leaf turnover rates and elevated nutrient availability have been implicated as causal factors for increased epiphyte loads in seagrass beds (Borum 1985. Twilley et al. 1985. Tomasko \& Lapointe 1991). Epiphyte abundance has been experimentally demonstrated to be a function of nutrient availability (Tomasko \& Lapointe 1991, Neckles et al. 1993, 1994; but see Bulthuis et al. 1992). Seagrass epiphyte density and biomass have also shown increases along nutrient availability gradients (Cambridge \& McComb 1984, Borum 1985, Silberstein et al. 1986). Due to relatively small regional variation in leaf productivity rates, seagrass leaf turnover rate will affect epiphyte dynamics more in the temporal domain than the spatial domain (Humm 1964, Borum 1985, Zieman et al. 1989, Tomasko \& Lapointe 1991, Frankovich 1996). Spatial differences in nutrient availability are believed to be major controls on regional variation in epiphyte loads.

Seagrass epiphytes are sessile plants and animals that grow attached to their seagrass host (Harlin 1980, Frankovich \& Zieman 1994). Epiphyte carbonate often accounts for as much as 70 to $80 \%$ of epiphyte standing stock (Heijs 1984, Frankovich \& Zieman 1994). This large amount of non-autotrophic mass in the epiphyte community may complicate the relationship between nutrient availability and epiphyte loads of seagrasses. Because autotrophs are the primary component of a community that responds to nutrient availability, some measure of autotrophic epiphyte biomass (e.g. epiphyte chlorophyll) should be more sensitive to nutrient availability than total (plant + animal) epiphyte load.

In this paper, we compare epiphyte loads, seagrass short shoot size, nutrient availability to seagrasses, and water column nutrient concentrations across a large tropical embayment. Large gradients in benthic and water column nutrient availability have been documented for this ecosystem (Zieman et al. 1989, Fourqurean et al. 1992a, 1993); nutrient availability ranged from limiting to seagrass and phytoplankton growth to adequate for dense seagrass growth (Powell et al. 1991, Fourqurean et al. 1992a, b, 1993). We document the spatial patterns in epiphyte abundance across the ecosystem, and test the hypothesis that epiphyte biomass (total epiphyte load and epiphyte chlorophyll load) would be correlated with the gradient in nutrient availability.

\section{METHODS}

Study site. This work was done in a shallow subtropical embayment, Florida Bay, Florida, USA (Fig. 1). Seagrasses, predominantly Thalassia testudinum, carpet ca $2000 \mathrm{~km}^{2}$ of Florida Bay. There is a strong gradient in seagrass density across the bay, with seagrass density in the western bay an order of magnitude higher than the eastern parts of the bay (Zieman et al. 1989). This gradient is the result of a strong gradient in benthic phosphorus availability; seagrass biomass in the eastern parts of Florida Bay is P-limited (Fourqurean et al. 1992a, b). In addition to the gradient in benthic nutrient availability, there is a corresponding gradient in water column nutrient availability, which leads to P-limitation of phytoplankton biomass (Fourqurean et al. 1993). We sampled seagrasses, epiphytes, and water column nutrients from 24 stations distributed across the seagrass and nutrient availability gradient. A bird colony island in eastern Florida Bay, Porjoe Key (Fig. 1), was also sampled for seagrasses and epiphytes; this bird colony is a local point source of nutrients in an otherwise oligotrophic portion of Florida Bay (Powell et al. 1991, Fourqurean et al. 1992a).

Seagrass and epiphyte sampling. On March 26-27, 1994, 6 arbitrary short shoots of Thalassia testudinum were collected from 24 long-term water quality monitoring sites within Florida Bay (Fig. 1). During August of 1991 and 1992,10 short shoots of $T$. testudinum were collected at each of 3 equally-spaced points located along a $45 \mathrm{~m}$ transect perpendicular to the shoreline of the bird colony island (Fig. 1). Macroscopic epiphytic organisms occurring on the leaves of the sampled short shoots were recorded. Organisms were identified to the lowest taxon practical, and a qualitative estimate was made of the relative abundance of each organism. Epiphytes were separated from the seagrass leaves by gentle scraping of lyophilized seagrass leaves (Frankovich \& Zieman 1995). The dry weight of the leaves of each short shoot and the dry weight of the epiphytes removed from each short shoot were recorded. Total epiphyte load (mg dry wt of epiphytes $\mathrm{g}^{-1}$ dry wt of seagrass leaf) was determined from the dry weight of the separated epiphyte material and the dry weight of scraped seagrass leaves.

For each of the 24 sites sampled in March 1994 . autotrophic epiphytes were quantified by extracting 


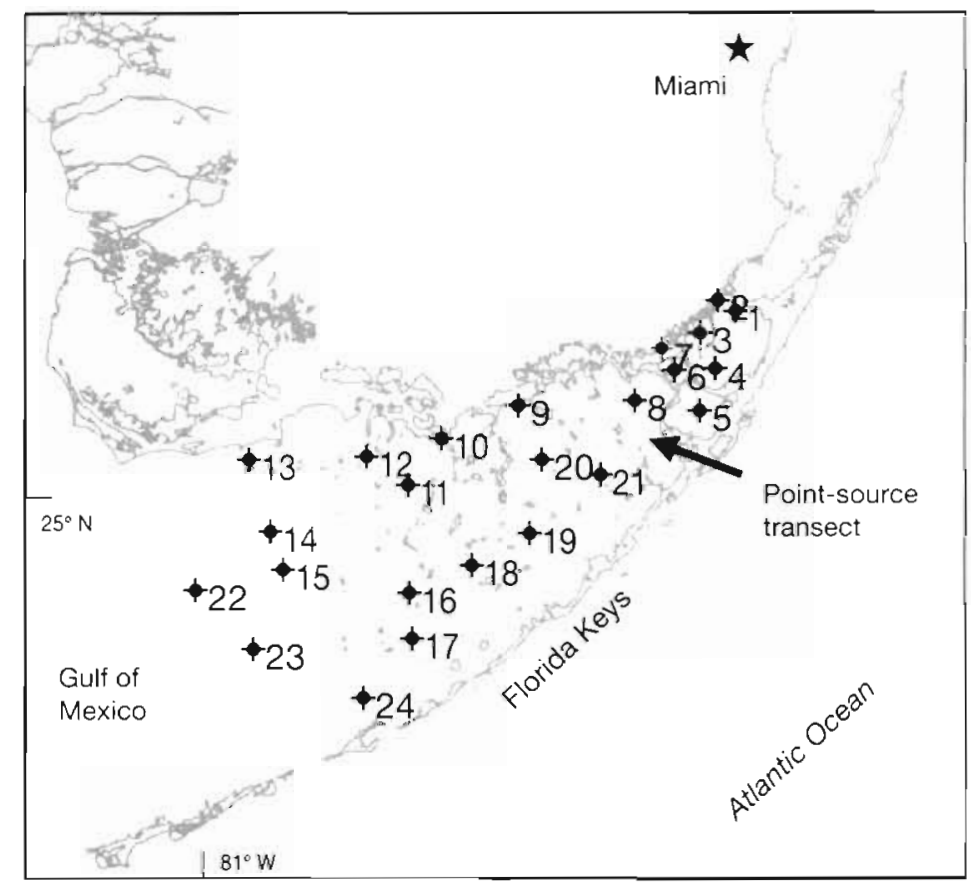

Fig. 1. Florida Bay, USA, showing sampling locations for seagrasses, epiphytes, and water quality data. The location of the Porjoe Key bird colony point source of nutrients transect is also shown

longer-term record (March 1991 to March 1994) of surface salinities was used to describe the salinity variability at each site. Water quality parameters collected for comparison to epiphyte loads were: concentrations of total organic nitrogen (TON), ammonium $\left(\mathrm{NH}_{4}^{+}\right)$, nitrate $\left(\mathrm{NO}_{3}^{-}\right)$, nitrite $\left(\mathrm{NO}_{2}^{-}\right)$, total phosphorus (TP), soluble reactive phosphorus (SRP), total organic carbon (TOC), and water column chl a, as well as salinity and turbidity. Methods for these water quality measurements are described elsewhere (Fourqurean et al. 1993).

Statistical methods. Before statistical analyses, all data were checked for normality, and were ln-transformed where appropriate. Statistical treatment of the total epiphyte loads measured at the 3 sites located along the nutrient point source transect was performed utilizing a 2-way ANOVA to detect significant differences in mean total epiphyte loads between sites and times. In the absence of a statistically significant time effect, a 1-way ANOVA with Scheffé's multiple comparison procedure $(0.05$ level of significance) was performed to detect significant differences between the time-av-

chlorophyll a (chl a) from the lyophilized epiphytes. The separated epiphyte material from each shoot was steeped in either 5.0 or $20.0 \mathrm{ml}$ (depending on total epiphyte weight) of $90 \%$ spectrophotometric grade acetone, and held in the dark below $0^{\circ} \mathrm{C}$ for a minimum of $36 \mathrm{~h}$ (Frankovich 1996). Chl a content of the acetone extracts was determined fluorometrically (Strickland \& Parsons 1972). Epiphyte chlorophyll load ( $\mu$ g chl a $\mathrm{mg}^{-1}$ seagrass leaves) was determined from the chl a content of the acetone extracts and the dry weight of scraped Thalassia testudinum leaves. In order to detect differences in the amount of algal epiphytism relative to faunal epiphytism, an autotrophic index ( $\mathrm{AI}=\mu \mathrm{g} \mathrm{chl} \mathrm{a} \mathrm{mg}^{-1}$ epiphyte) was determined.

The availability of nutrients to the seagrasses was assessed by analyzing the carbon, nitrogen, and phosphorus content of the seagrass leaves at each site (Fourqurean et al. 1992a, b). C and $\mathrm{N}$ content was determined by analyzing triplicate samples of the scraped seagrass leaves using a Carlo Erba CN analyzer. Phosphorus content of the same material was determined following a dry oxidation/acid hydrolysis procedure (Fourqurean et al. 1992a). Ratios of C, N, and $\mathrm{P}$ were calculated on a molar basis.

Water quality sampling. Mean values of monthly water quality data were determined for the 2 mo period prior to sampling (the seagrass/epiphyte turnover period for Florida Bay; Zieman et al. 1989). A eraged transect point means. Univariate relationships between water quality, seagrass, and epiphyte variables were checked using Pearson correlation. To define the independent underlying patterns in the nutrient availability data, a Principal Components Analysis, using the correlation matrix, was done on the nutrient availability data. The final solution was rotated to allow for interpretation of the principal components using a VARIMAX rotation. Stepwise multiple regression was used to determine which of the nutrient availability principal components explained significant portions of the variability in the epiphyte loads and seagrass morphology. We deemed significant only independent variables with partial $F$ significant at $\mathrm{p} \leq 0.05$.

\section{RESULTS}

\section{Seagrass distribution}

There was a strong gradient in the amount of green leaf material per short shoot of Thalassia testudinum across Florida Bay (Fig. 2). Short shoot (ss) size ranged from a low of $34 \mathrm{mg}$ green leaf $\mathrm{ss}^{-1}$ at Stn 19 to a high of $525 \mathrm{mg}$ green leaf $\mathrm{ss}^{-1}$ at Stn 13 . There were relatively few stations with large short shoots; the median for the whole bay was $80 \mathrm{mg}$ green leaf $\mathrm{ss}^{-1}$. In general, short shoot size was smallest in eastern and central 


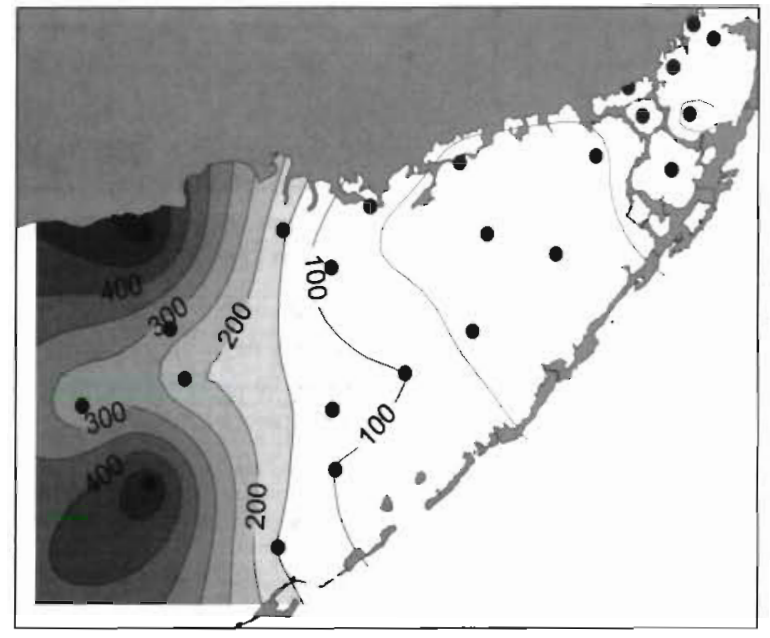

Fig. 2. Thalassia testudinum. Spatial distribution of the amount of green leaf material per seagrass short shoot $\left(\mathrm{mg} \mathrm{ss}^{-1}\right)$

Florida Bay, and largest along the western boundary of the bay (Fig. 2). This gradient in short shoot size was mirrored by a gradient in $\mathrm{P}$, but not $\mathrm{N}$, content of the leaves. C:P of $T$. testudinum leaves generally increased from a minimum of 486 in the northwest part of Florida Bay to a maximum of 1807 at Stn 8 in eastern Florida Bay (Fig. 3b). The pattern in $\mathrm{C}: \mathrm{N}$ of $\mathrm{T}$ testudinum leaves was quite different, with a minimum of 11 at Stn 11 in the center of the bay. C:N increased in all directions from the center of the bay; the maximum C:N was 21 at Stn 7 (Fig. 3a). C:P was strongly correlated with short shoot size (Fig. 4), but C:N was not $\left(\mathrm{r}^{2}=0.00, \mathrm{p}=0.807\right)$. The one point that deviated strongly from the relationship between $C: P$ and shoot size was $\operatorname{Stn} 11$, where the shoot size was much smaller than predicted by the P content of the leaves (Fig. 4).

\section{Epiphyte abundance}

We identified 7 macroscopic algal and 11 faunal taxa that were epiphytic on the leaves of the sampled short shoots during the March 1994 sampling period (Table 1). All identified macroscopic algae were red algae (Rhodophyta). The epiphytic faunal composition was more diverse than the algal composition. Five phyla (Annelida, Bryozoa, Chordata, Hydrozoa, and Mollusca) were represented. Epiphyte occurrence and abundance were dominated by the coralline red algae Melobesia membranacea and Fosliella farinosa and the polychaete Spirorbis sp. Spirorbis sp. was the most ubiquitous epiphyte taxon, occurring at $75 \%$ of the sites, and was the most abundant epiphyte at $58 \%$ of the sites. The coralline red algae were the most abundant and ubiquitous of the algal species, occurring at
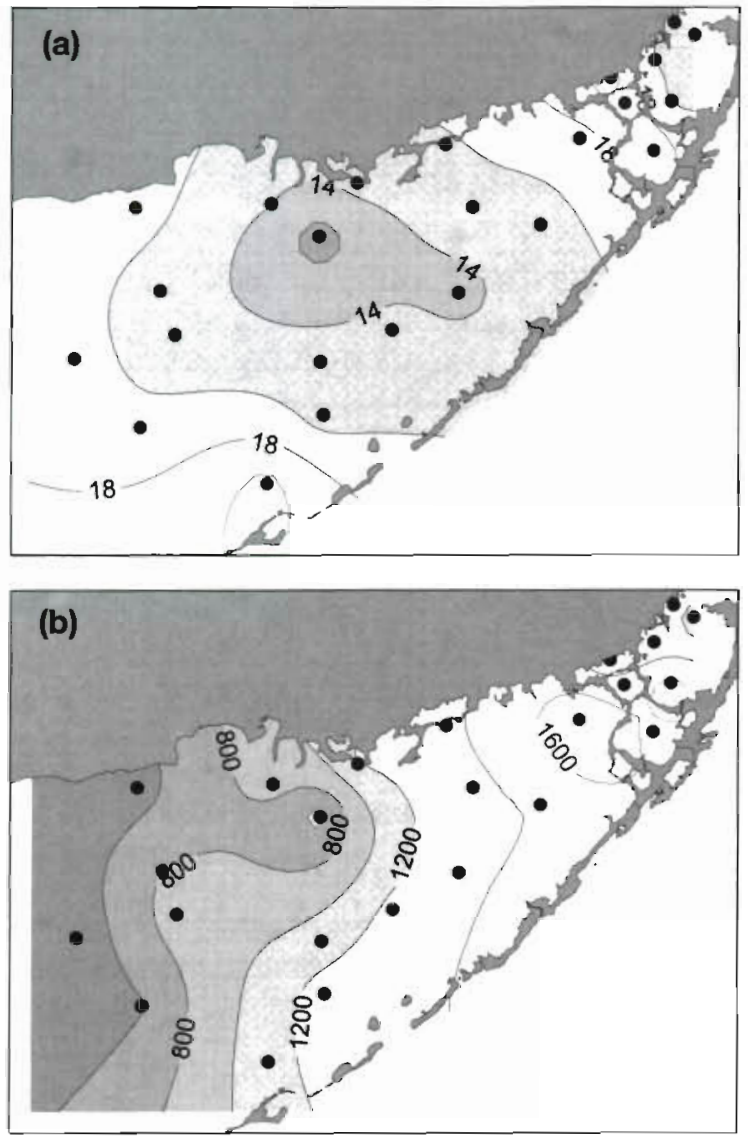

Fig. 3. Thalassia testudinum. Spatial distribution of (a) $\mathrm{C}: \mathrm{N}$ ratio of green seagrass leaves, and (b) C:P of green seagrass leaves

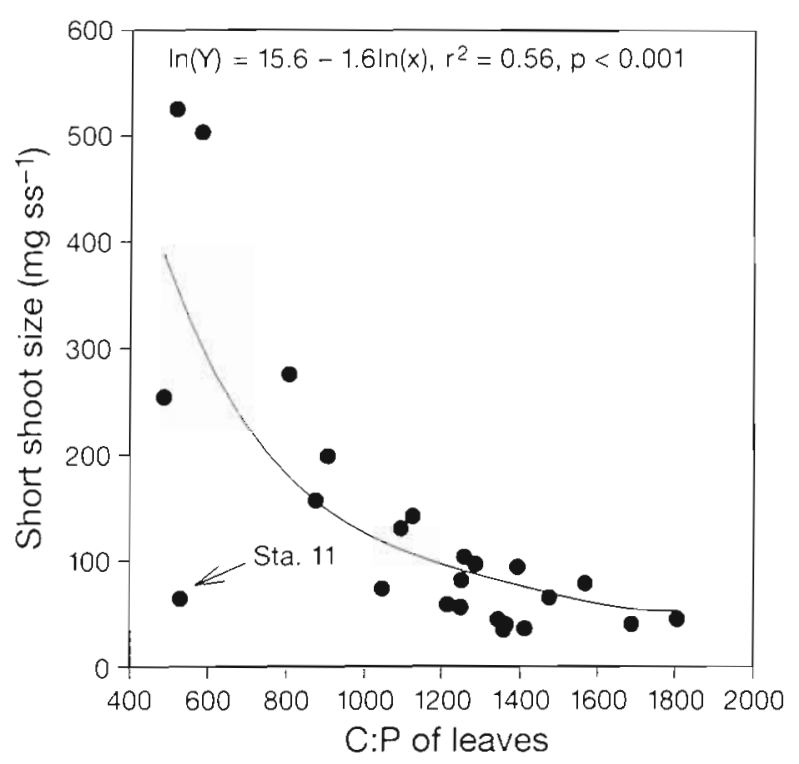

Fig. 4. Thalassia testudinum. Seagrass short shoot size (mass of green leaves per short shoot) as a function of $\mathrm{P}$ content of the leaves. Solid line represents the linear regression; regression statistics are shown on the tigure 
Table 1. Macroscopic algal and faunal epiphytes occurring on leaves of sampled short shoots of Thalassia testudinum from each of the individual sites located in Fig. 1 Epiphytes are listed in order of abundance. Numerals and capital letters correspond to algal and faunal epiphytes, respectively. Algal epiphytes: 1, Coralline algae (Melobesia membranacea, Fosliella farinosa); 2, Ceramium spp.; 3, Spyridia spp.; 4, Hypnea sp.; 5, Laurencia spp.; 6, Amphiroa fragilissima sp. Faunal epiphytes: A, polychaete (Spirorbis sp.); B, mollusc (Pinctada imbricata); C, mollusc (Brachidontes exustus); D, encrusting tunicates (Botryllus planus, Botrylloides nigrum); $\mathrm{E}$, colonial tunicate (Perophora sp.); F, unidentified bryozoan; G, unidentified chiton; H, hydrozoan (Sertularia sp.); I, unidentified tube-forming polychaete; J, Soritid foraminifera; K, unidentified hydrozoan

\begin{tabular}{|c|c|c|}
\hline Site no. & Algal epiphytes & Faunal epiphytes \\
\hline 1 & . & . \\
\hline 2 & 1,3 & A \\
\hline 3 & 1,3 & - \\
\hline 4 & 2,1 & A \\
\hline 5 & 3,1 & G \\
\hline 6 & 1 & C,I \\
\hline 7 & & $\mathrm{C}$ \\
\hline 8 & 1,2 & $\mathrm{~A}, \mathrm{~B}, \mathrm{G}$ \\
\hline 9 & 1,3 & A \\
\hline 10 & • & A \\
\hline 11 & • & $F, A, J$ \\
\hline 12 & $\cdot$ & $\mathrm{F}, \mathrm{H}, \mathrm{A}, \mathrm{E}, \mathrm{C}, \mathrm{G}$ \\
\hline 13 & 4 & $\mathrm{~F}, \mathrm{~A}$ \\
\hline 14 & 1 & A \\
\hline 15 & 1 & A \\
\hline 16 & • & A \\
\hline 17 & • & A \\
\hline 18 & • & $\mathrm{A}, \mathrm{C}$ \\
\hline 19 & - & A \\
\hline 20 & 4 & A \\
\hline 21 & $\cdot$ & A \\
\hline 22 & 1,4 & - \\
\hline 23 & $1,5,6$ & $D, A, K$ \\
\hline 24 & 1 & $\mathrm{~A}, \mathrm{~F}$ \\
\hline \multicolumn{3}{|c|}{ - No epiphytes identified } \\
\hline
\end{tabular}

$50 \%$ of the sites and being most abundant at $42 \%$ of the sites. Heavy carbonate encrustations were formed by these species at those sites in western Florida Bay where water is exchanged more freely with the Gulf of Mexico and the Atlantic Ocean.

The abundance of epiphytes, when measured on a per short shoot basis, was greatest in western Florida Bay and decreased eastward (Fig. 5a). There was a broad range ( 1.7 to $824 \mathrm{mg} \mathrm{ss}^{-1}$ ) in epiphyte abundance across the bay, with a median abundance of $79.7 \mathrm{mg}$ $\mathrm{ss}^{-1}$. Given the spatial gradient in short shoot size, short-shoot-based measures of epiphyte abundance do not accurately reflect the effect of epiphytes on seagrasses, however. Normalizing this measure by the size of the short shoots gives a better estimate of the epiphyte load on the seagrasses. Total epiphyte load ranged from 23 to $1569 \mathrm{mg}$ epiphyte $\mathrm{g}^{-1}$ seagrass, with
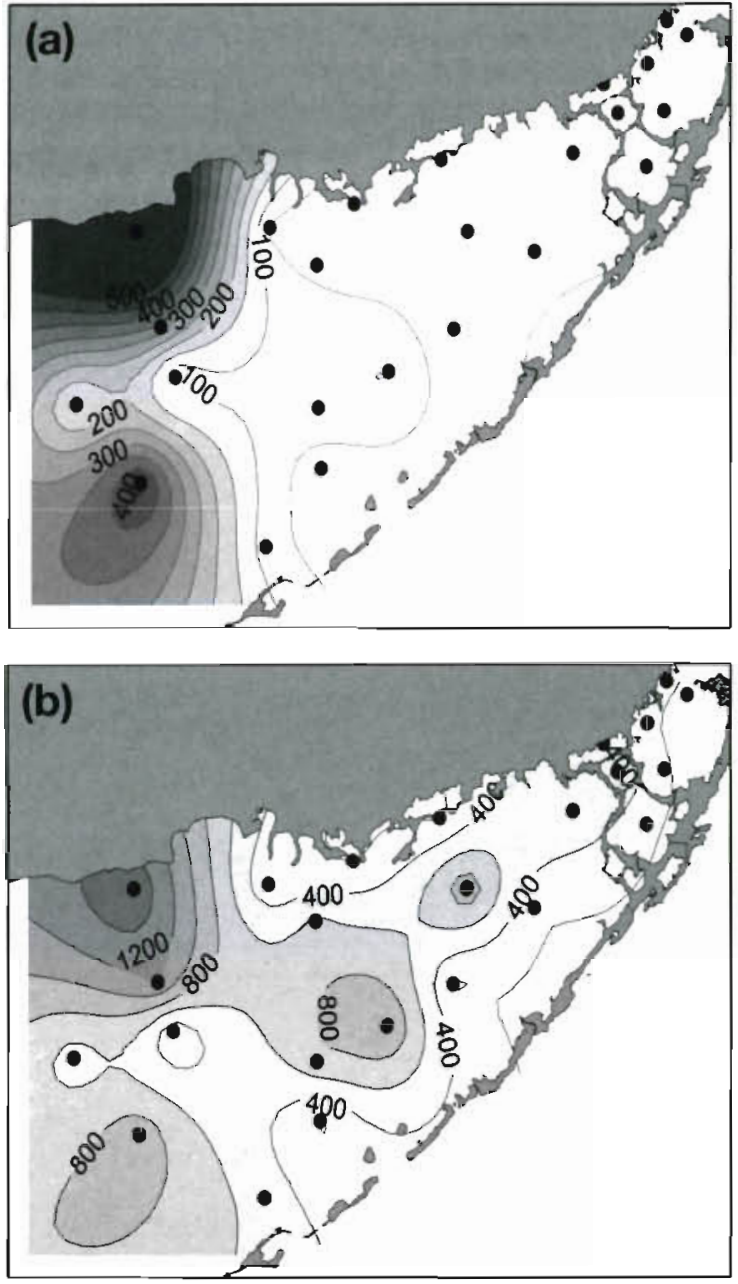

Fig. 5. Thalassia testudinum. Spatial distribution of (a) total epiphyte abundance per short shoot of seagrass and (b) total epiphyte load as mass of epiphytes per $\mathrm{g}$ of seagrass leaves $\left(\mathrm{mg} \mathrm{g}^{-1}\right)$

a median load of $376 \mathrm{mg} \mathrm{g}^{-1}$. The spatial pattern in total epiphyte load was not as clear as the pattern in epiphyte abundance (Fig. 5b). In general, epiphyte load was highest in western Florida Bay, but there were also peaks in epiphyte load at Stns 18 and 20 in central Florida Bay.

Similar to total epiphyte abundance, autotrophic epiphyte abundance also was highest in northwestern Florida Bay (Fig. 6a). The median epiphyte chl a abundance was $2.7 \mu \mathrm{g} \mathrm{ss}{ }^{-1}$, with a range of 0.1 to $106 \mu \mathrm{g} \mathrm{ss}^{-1}$. Epiphyte chlorophyll loads ranged from $1.5 \mu \mathrm{g} \mathrm{g}^{-1}$ at $\operatorname{Stn} 1$ in the east to $298.7 \mu \mathrm{g} \mathrm{g} \mathrm{g}^{-1}$ at $\operatorname{Stn} 14$ in northwestern Florida Bay (Fig. 6b). The median epiphyte chlorophyll load was $34.8 \mu \mathrm{g} \mathrm{g} \mathrm{g}^{-1}$. Almost two-thirds $(62.5 \%)$ of the sites had mean epiphyte chlorophyll loads less than $50 \mu \mathrm{g} \mathrm{g}^{-1}$. Aside from the high epiphyte chlorophyll loads measured at Stns 18 

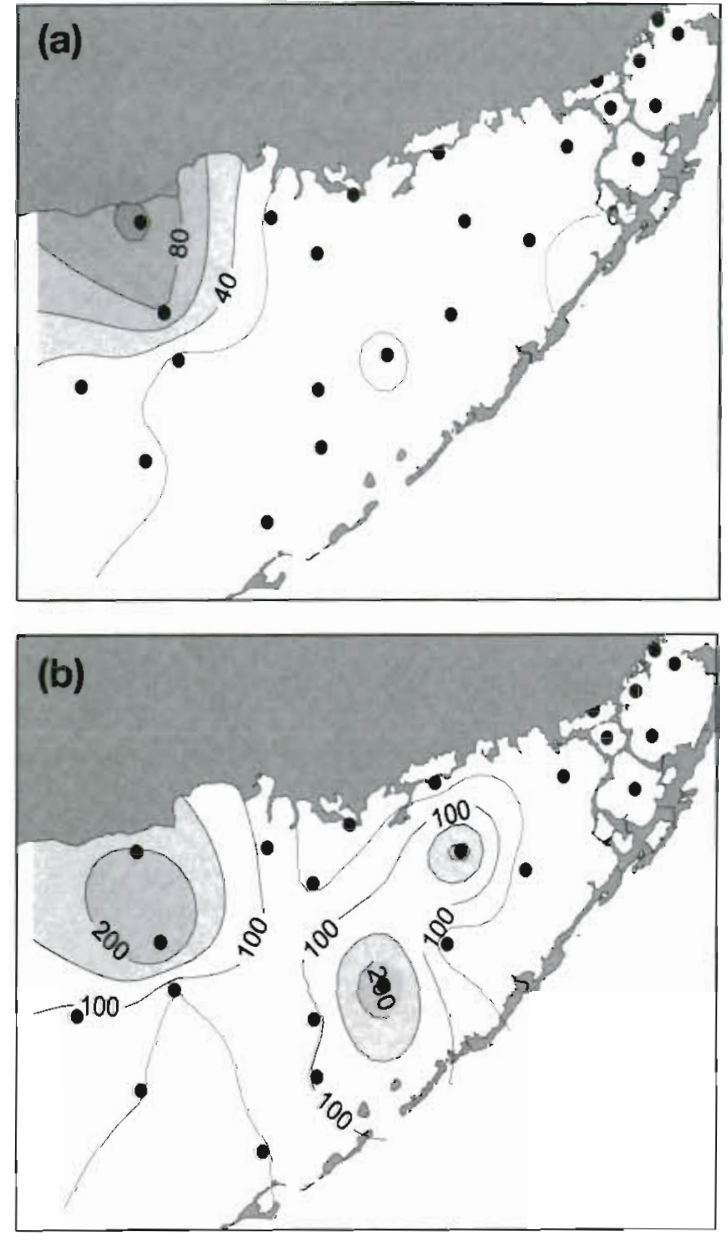

Fig. 6. Thalassia testudinum. Spatial distribution of (a) epiphyte chl a abundance per short shoot of seagrass ( $\mathrm{mg} \mathrm{ss}^{-1}$ ); and (b) epiphyte chl a load as mass of epiphytes per $\mathrm{g}$ of seagrass leaves $\left(\mathrm{mg} \mathrm{g}^{-1}\right.$ )

and 20, mean epiphyte chlorophyll loads generally decreased from higher values in northwest Florida Bay to lower values in extreme northeastern Florida Bay (Fig. 6b)

There was not a constant assemblage of autotrophs and heterotrophs making up the total epiphyte load. The autotrophic index (AI) ranged from $0.02 \mu \mathrm{g} \mathrm{mg}^{-1}$ at Stn 8 in northeastern Florida Bay to $0.68 \mu \mathrm{g} \mathrm{mg}^{-1}$ at Stn 17 in southwestern Florida Bay. More than half of the sites (54.2\%) had AIs less than $0.1 \mu \mathrm{g} \mu^{-1}$. AIs tended to be lower in northeastern Florida Bay, with higher values towards the southwestern and northwestern areas of Florida Bay (Fig. 7)

At the 24 water quality monitoring sites, all measures of epiphyte abundance and load were low in eastern Florida Bay relative to western Florida Bay, owing to the general oligotrophic nature of eastern Florida Bay. The coralline red algae were most abundant in west- ern Florida Bay while the occurrence of the polychaete Spirorbis sp. and the molluscs Brachidontes exustus and Pinctada imbricata increased towards the more restricted eastern Florida Bay. Total epiphyte loads were anomalously high near Porjoe Key, the point source of nutrients in eastern Florida Bay. Mean total epiphyte loads measured along the transect near the point source ranged from 10.6 to $399.0 \mathrm{mg} \mathrm{g}^{-1}$ (Fig. 8). The results of the 2 -waY ANOVA indicate significant differences only between transect points. As a result of the lack of a significant difference between sampling times, Scheffé's multiple comparison procedure was performed on the time-averaged transect point means Time-averaged mean epiphyte loads were significantly higher $(F=13.2, \mathrm{p}<0.001)$ at the transect point located in closest proximity to the bird island. Mean epiphyte loads were 3 to 36 times higher at the transect point located closest to the island than at those located further away. Significant differences in the time-averaged mean epiphyte loads were only evident between the closest point to the nutrient source and the 2 more distally located points (Scheffé's, $p<0.05$ ).

\section{Water quality sampling}

In February and March 1994, Florida Bay was a polyhaline estuary, with salinities from $18.3 \mathrm{psu}$ in the northeast to 35.4 psu in the center of the bay (Table 2 . Fig. 9a). Fully two-thirds of the bay was characterized by water approximating marine salinity ( -34 psu). This is in contrast to the historic salinity characteristics of the bay. Salinity can vary widely in this system, from freshwater in the northeast reaches of the bay to over 60 psu over much of the central and eastern portions of the bay. The southwest margin has the lowest vari-

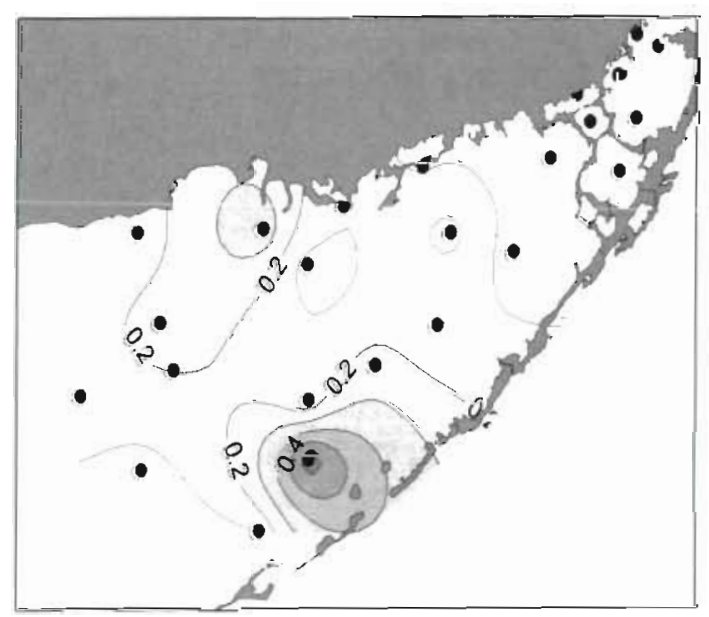

Fig. 7. Thalassia testudinum. Spatial distribution of epiphyte community autotrophic index ( $\mu \mathrm{g} \mathrm{chl} \mathrm{mg}^{-1}$ epiphyte) 


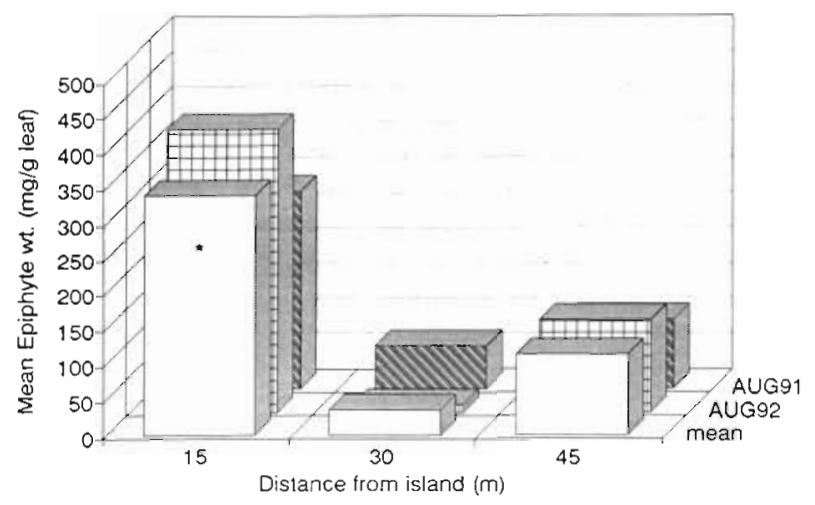

Fig. 8. Thalassia testudinum. Total epiphyte load as a function of distance from a point source of nutrients at the Porjoe Key bird colony. - denotes significant differences between the time-averaged transect point mean at $15 \mathrm{~m}$ and the 2 more distally located transect points (Scheffé, $p<0.05$ )

ability in salinity, with a range of 10 psu over the period 1990 to 1994, while salinity in waters adjacent to the mainland have varied over 48 psu (Fig. 9b).

Water column nutrient concentrations varied across Florida Bay for the 2 mo preceding the March 1994 seagrass and epiphyte sampling (Table 2). Total organic carbon (TOC) ranged from 220 to $1410 \mu \mathrm{M}$ with the higher values from sites in central Florida Bay. Organic forms of nitrogen and phosphorus dominated the nutrient pool, constituting approximately $90 \%$ of respective total concentrations of these nutrients. Concentrations of both DIP (range 0.01 to $0.33 \mu \mathrm{M}$, median $=0.03 \mu \mathrm{M}$ ) and $\mathrm{TP}$ (range 0.2 to $1.7 \mu \mathrm{M}$, median = $0.4 \mu \mathrm{M}$ ) were quite low baywide (Fig. 10). Maximum DIP was found in the center of Florida Bay, while

Table 2. Summary statistics for baywide water quality at 24 stations for February-March 1994, Florida Bay, USA. DO: dissolved oxygen; TOC: total organic carbon; DIN: dissolved inorganic nitrogen; TON: total organic nitrogen; TN: total nitrogen; DIP: dissolved inorganic phosphorus; TP: total phosphorus

\begin{tabular}{|lccccc|}
\hline & Min. & Max. & Median & Mean & SD \\
\hline Salinity (psu) & 18.3 & 35.4 & 32.9 & 30.9 & 4.3 \\
Temp. $\left({ }^{\circ} \mathrm{C}\right)$ & 21.0 & 23.9 & 22.6 & 22.5 & 0.9 \\
DO (mg l $\left.{ }^{-1}\right)$ & 6.2 & 7.6 & 7.0 & 7.0 & 0.4 \\
Turbidity (NTU) & 0.9 & 188.1 & 26.8 & 38.4 & 44.6 \\
TOC $(\mu \mathrm{M})$ & 220 & 1410 & 744 & 815 & 312 \\
NO$_{3}^{-}(\mu \mathrm{M})$ & 0.08 & 6.47 & 0.97 & 1.66 & 1.74 \\
$\mathrm{NO}_{2}^{-}(\mu \mathrm{M})$ & 0.11 & 0.80 & 0.31 & 0.34 & 0.18 \\
$\mathrm{NH}_{4}{ }^{+}(\mu \mathrm{M})$ & 1.02 & 18.25 & 3.26 & 5.37 & 4.89 \\
DIN $(\mu \mathrm{M})$ & 1.21 & 21.96 & 4.89 & 7.38 & 5.95 \\
TON $(\mu \mathrm{M})$ & 17.6 & 136.8 & 46.2 & 52.9 & 29.7 \\
TN $(\mu \mathrm{M})$ & 19.6 & 142.1 & 51.3 & 60.3 & 30.4 \\
DIP $(\mu \mathrm{M})$ & 0.01 & 0.33 & 0.03 & 0.07 & 0.09 \\
TP $(\mu \mathrm{M})$ & 0.21 & 1.67 & 0.37 & 0.57 & 0.41 \\
Chl a $\left.(\mu \mathrm{g} \mathrm{l})^{-1}\right)$ & 0.6 & 6.9 & 1.6 & 2.5 & 2.1 \\
& & & & & \\
\hline
\end{tabular}

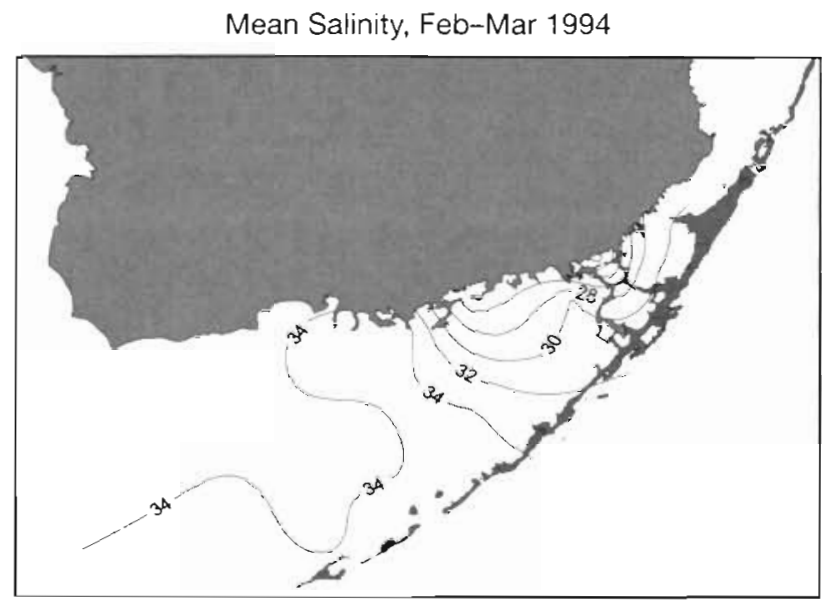

\section{Salinity Range, 1990-1994}

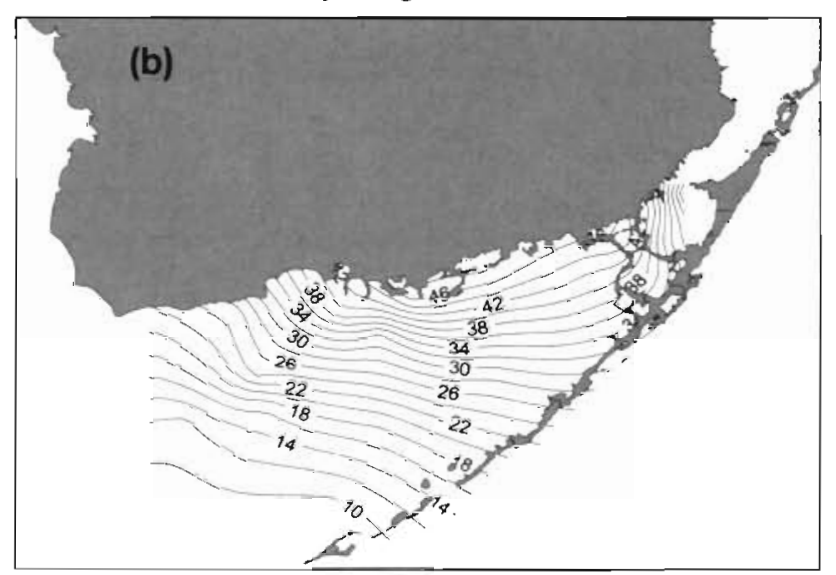

Fig. 9. Distribution of surface salinity in Florida Bay. (a) Mean of data collected in February-March 1994; and (b) range in salinity values over the period 1991 to 1994

maximum TP was found in northwest Florida Bay. In contrast to $\mathrm{P}$, concentrations of TN (range 19.6 to $142.1 \mu \mathrm{M})$ and DIN $(1.2$ to $22.0 \mu \mathrm{M})$ were relatively high (Fig. 10). Peak DIN $(22.0 \mu \mathrm{M})$ was found in eastern Florida Bay; TN was maximum in the north-central part of the bay. Water column chl a concentrations were low across the bay (range 0.6 to $6.9 \mu \mathrm{g} \mathrm{l}^{-1}$, median $=1.6 \mu \mathrm{g} \mathrm{l}^{-1}$ ).

Many of the indicators of nutrient availability, seagrass biomass, and epiphyte abundance were correlated (Table 3; for example, compare the distribution of C:P of Thalassia testudinum leaves, Fig. 3b, with the distribution of water column TP, Fig. 10a). In order to define independent underlying patterns in the nutrient availability data, a Principal Components Analysis was done on the ln-transformed nutrient availability data. Four Principal Components (PC1 through PC4) were extracted from the data that described $86 \%$ of the variation in the original data set (Table 4). PC1 was highly correlated with measures of inorganic nitrogen con- 

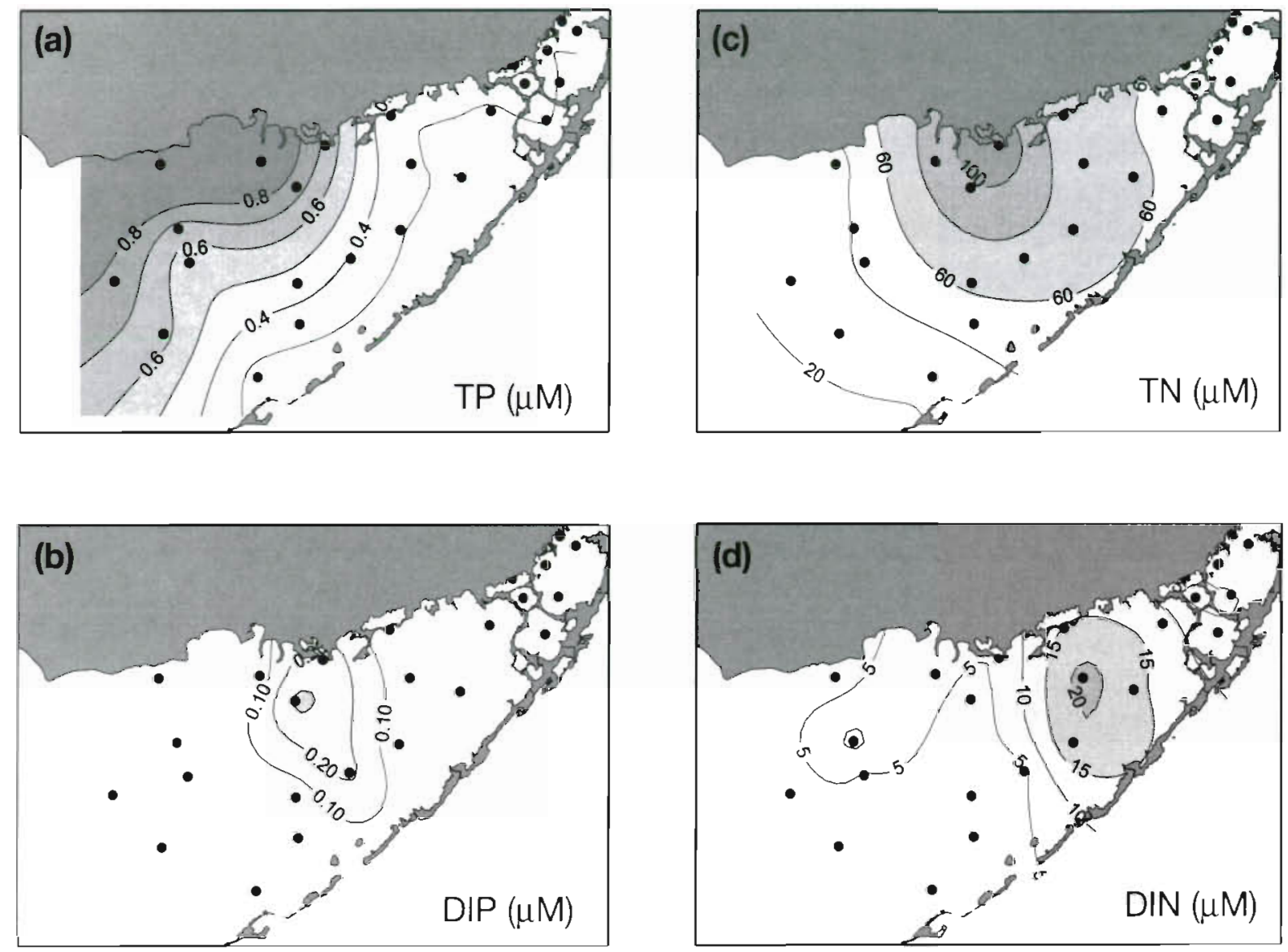

Fig. 10. Distribution of concentrations of (a) TP (b) DIP (c) TN and (d) DIN in the water column during February-March 1994

centration in the water column, and accounted for $27.9 \%$ of the variance in the original data set. PC2 was positively correlated with $\mathrm{TN}, \mathrm{TON}, \mathrm{TOC}$, and DIP concentrations in the water column. We interpreted this factor, which explained $25.5 \%$ of the variation, to be an indicator of dissolved organic matter in the water column. A further $21.7 \%$ of the variation in the nutrient availability data set was explained by $\mathrm{PC} 3$, which was positively correlated with TP, turbidity, and chl a concentrations in the water column and negatively correlated with C:P of $T$. lestudinum leaves. This factor represented $P$ availability in both the water column and the seagrass bed. A fourth principal component (PC4) was significantly correlated with salinity and $\mathrm{N}$ content of $T$. testudinum leaves; PC4 explained an additional $11.2 \%$ of the variation in the nutrient availability data set.

Since the aim of this paper was to describe how epiphyte loads on seagrass were determined by various measures of nutrient availability, we used the factor scores of the principal components extracted from the nutrient availability data set as independent variables in stepwise regression to describe the shoot size, total epiphyte load, epiphyte chlorophyll load and AI for each station. The mass of short shoots of Thalassia testudinum in Florida Bay was positively related to $\mathrm{P}$ availability (PC3), but negatively related to dissolved inorganic $\mathrm{N}$ concentration (PC1) and dissolved organic matter (PC2) in the water column. The equation $\ln ($ short shoot size $)=4.5+0.5(\mathrm{PC} 3)-0.4(\mathrm{PC} 2)-$ $0.3(\mathrm{PC} 1)$ had an adjusted multiple $\mathrm{r}^{2}$ of 0.745 , with partial $F$ for all factors $>15, p$ for all factors $\leq 0.001$. Total epiphyte load on $T$. testudinum from Florida Bay was significantly, albeit weakly, related to only $P$ availability $\left[\ln \left(\right.\right.$ total epiphyte load) $=5.9+0.4(\mathrm{PC} 3), \mathrm{r}^{2}=$ $0.14, p=0.04$ ]. Similarly, epiphyte chlorophyll load was significantly, but weakly, related to $P$ availability. An example of the raw data indicates the pattern of the relationship between $P$ availability and epiphyte chlorophyll load (Fig. 11a); the generalized relationship between epiphyte chlorophyll load and $P$ availability, as represented by PC3, is significant (Fig. 11b), although $\mathrm{P}$ availability explains only $17.4 \%$ of the variation. None of the principal components was significantly correlated with the AI of the epiphyte community, however. 


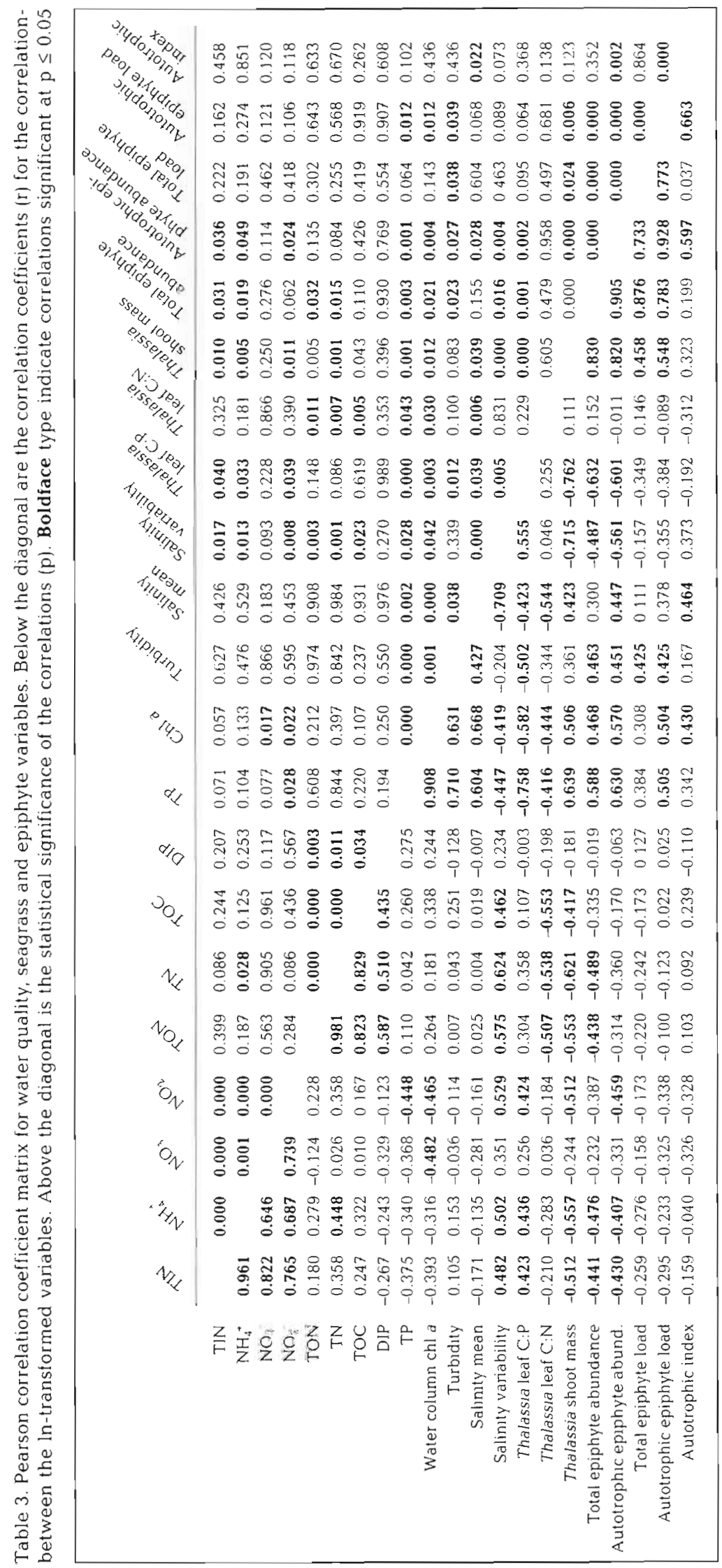

\section{DISCUSSION}

We measured gradients in water column nutrients, benthic nutrient availability, short shoot size of the seagrass Thalassia testudinum, and the abundance of epiphytes per short shoot in Florida Bay. During the March 1994 sampling, a period of maximal epiphyte abundance on seagrass in South Florida (Frankovich 1996), total epiphyte load and epiphyte chlorophyll load were weakly correlated with measures of nutrient availability, specifically phosphorus availability (PC3). Over the course of a year, we also measured the strong influence of a point source of nutrients on total epiphyte loads in the oligotrophic eastern part of Florida Bay. Our results demonstrate that, at the time of sampling, both water column and benthic nutrient availability may play a role in structuring the epiphytic community in this subtropical seagrass bed, but that the relationship between nutrient availability and epiphyte load alone cannot accurately predict the epiphyte loads at any station in Florida Bay.

There are large gradients in nutrient availability across Florida Bay, and biomass of phytoplankton and the dominant seagrass Thalassia testudinum has been shown to be phosphorus limited (Fourqurean et al. 1992a, 1993). We measured a host of factors related to nutrient availability; Principal Components Analysis indicated that the various proxies for nutrient availability could be reduced to 4 factors: inorganic nitrogen concentration, dissolved organic matter in the water column, phosphorus availability, and a factor related to benthic $N$ availability and water column salinity (Table 4). Due to high rates of in situ biogenic mud production (Nelsen \& Ginsburg 1986, Bosence 1989, Frankovich \& Zieman 1994), the water column is the ultimate source of nutrients for the benthos of Florida Bay over geologic time. This results in the strong correlation between water column measures of $N$ and $P$ concentration with the $N$ and $P$ content of the seagrass leaves (Tables 3 \& 4). Because other primary producers are $\mathrm{P}$ limited in Florida Bay, it is reason- 
Table 4. PCA results. Factor loadings for 4 principal components (PC1, inorganic $N_{i} P(: 2$, dissolved organic matter; PC3, phosphorus availability; PC4, salinity and Thalassia testudinum leaf $\mathrm{N}$ ). Loadings are the correlation between the natural-log transforms of the data with the principal components. Correlations greater than 0.5 are highlighted in bold type. In total, the 4 principal components explained $86.3 \%$ of the variation in the original data set

\begin{tabular}{|lrrrr|}
\hline Original variable & PC1 & PC2 & PC3 & PC4 \\
\hline TIN & $\mathbf{0 . 9 7 1}$ & 0.118 & -0.080 & -0.014 \\
$\mathrm{NH}_{4}{ }^{+}$ & $\mathbf{0 . 9 1 5}$ & 0.212 & -0.064 & 0.038 \\
$\mathrm{NO}_{3}{ }^{-}$ & $\mathbf{0 . 8 5 8}$ & -0.158 & -0.076 & -0.185 \\
$\mathrm{NO}_{2}{ }^{-}$ & $\mathbf{0 . 8 0 5}$ & 0.138 & -0.307 & 0.096 \\
TON & 0.075 & $\mathbf{0 . 9 6 5}$ & -0.061 & 0.137 \\
TN & 0.253 & $\mathbf{0 . 9 3 9}$ & -0.064 & 0.141 \\
TOC & 0.195 & $\mathbf{0 . 8 7 2}$ & 0.247 & 0.012 \\
DIP & -0.409 & $\mathbf{0 . 7 1 4}$ & -0.031 & -0.067 \\
TP & -0.337 & 0.162 & $\mathbf{0 . 9 0 3}$ & 0.264 \\
Turbidity & 0.190 & 0.024 & $\mathbf{0 . 8 6 0}$ & 0.109 \\
Chl a & -0.377 & 0.270 & $\mathbf{0 . 7 3 3}$ & 0.380 \\
Thalassia leaf C:P & 0.328 & 0.259 & $-\mathbf{0 . 7 3 8}$ & -0.179 \\
Thalassia leaf C:N & -0.207 & -0.462 & -0.287 & $\mathbf{- 0 . 6 9 5}$ \\
Mean salinity & -0.147 & -0.060 & 0.374 & $\mathbf{0 . 8 6 4}$ \\
Variance explained & $27.9 \%$ & $25.5 \%$ & $21.7 \%$ & $11.2 \%$ \\
& & & & \\
\hline
\end{tabular}

able to expect that epiphytic algae within this system may also be $P$ limited. At the time of sampling, both total epiphyte load and epiphyte chlorophyll load were significantly correlated with $\mathrm{P}$ availability in Florida Bay, suggesting that the autotrophic component of the epiphyte community may also be $\mathrm{P}$ limited.

$\mathrm{P}$ availability explained only $14 \%$ of the variation in total epiphyte load and $17 \%$ of the epiphyte chlorophyll load, but the majority of the variability in water column chl a concentrations has been described by water quality nutrient variables, particularly those of phosphorus availability (Fourqurean et al. 1993). A stepwise multiple linear regression revealed that $83 \%$ of the variation in water column chl a can be explained by total phosphorus concentrations $(r=0.91, p<0.001)$. This disparity suggests that the factors controlling epiphyte accumulation are different from those controlling phytoplankton levels.

Relative $\mathrm{P}$ availability is a primary factor determining the biomass of benthic plants in Florida Bay (Fourqurean et al. 1992a), but it is not the only factor. Since 1987, Florida Bay has experienced the rapid decline in seagrass biomass in areas that formerly supported dense Thalassia testudinum communities; over 40000 ha have been affected by this die-off (Robblee et al. 1991, Durako 1994). While the causes of this phenomenon are not well understood, the changes in the ecosystem caused by the death of the dominant primary producer have been followed closely. Epi-
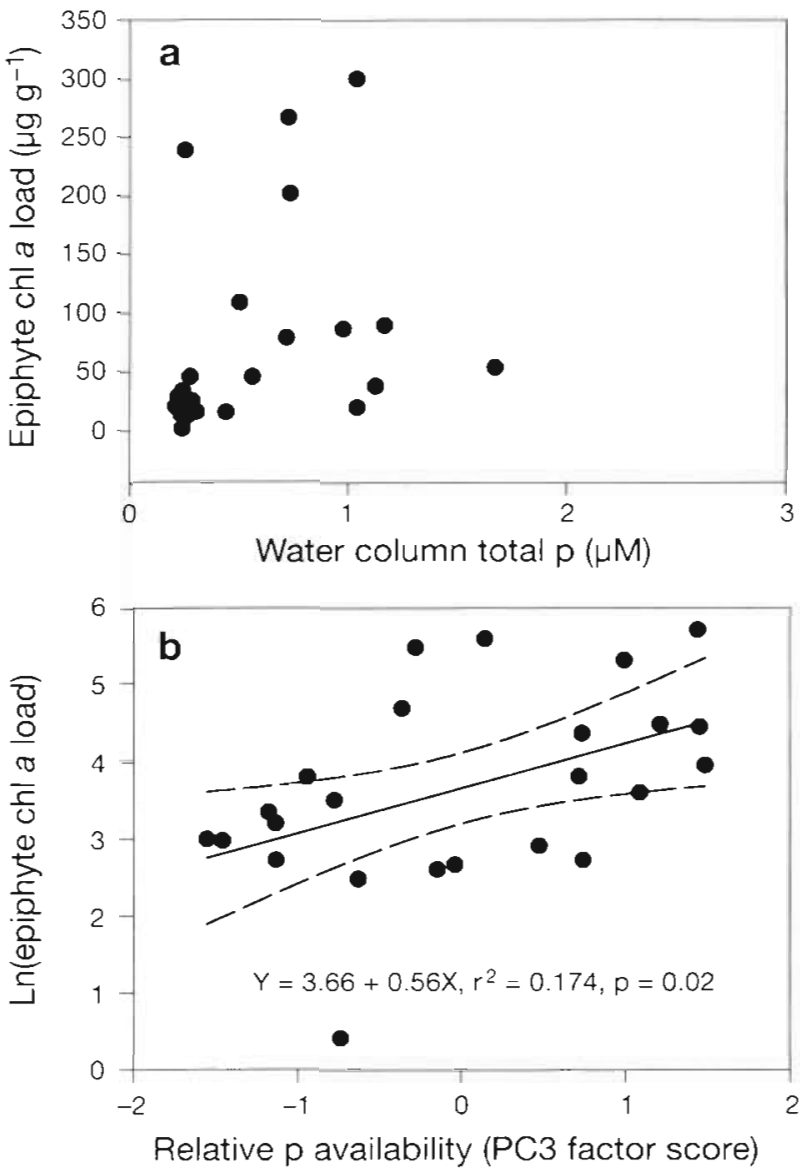

Fig. 11. Thalassia testudinum. Relationship between $P$ availability and epiphyte chl a load in Florida Bay

phytism did not play a role in the initial loss of seagrasses (Robblee et al. 1991, J.W.F. pers. obs.), but nutrient releases subsequent to the death of seagrasses led to increased phytoplankton concentrations in areas that had experienced seagrass mortality (Phlips \& Badylak 1996). We also noted heavy accumulations of benthic diatoms on the leaves of surviving seagrasses in the months following the die-off; we believe that the increased microalgae in the water column and epiphytic on the seagrasses was stimulated by nutrients released by decaying seagrasses. Data on the $N$ and $P$ content of seagrass leaves from both before and after the die-off show that these nutrient releases did not appreciably change the regional pattern of relative $N$ and $\mathrm{P}$ availability in Florida Bay. The spatial distributions of $T$. testudinum leaf $\mathrm{C}: \mathrm{P}$ and $\mathrm{C}: \mathrm{N}$ ratios measured in this study (Fig. 3) are identical to those observed prior to seagrass die-off (Fourqurean et al. 1992a). This indicates that the massive seagrass die-off that drastically decreased $T$. testudinum biomass and shoot density did not affect the wholesale distribution of nutrients within the ecosystem. 
The amount of Thalassia testudinum leaf biomass determines the amount of space available for colonization and growth of epiphytic biomass because the leaf biomass to leaf area ratio is constant (T.A.F. unpubl. data). The trend of increasing $T$. testudinum short shoot size from eastern towards western Florida Bay (Fig. 2) was similar to the gradient in seagrass standing crop in the ecosystem (Zieman et al. 1989). The regional distribution of $T$. testudinum leaf biomass per short shoot (Fig. 2) and epiphyte abundance per short shoot (Fig. 5) showed a similar pattern. In Florida Bay, approximately $35 \%$ of the variation in epiphyte material on $T$. testudinum short shoots can be accounted for by leaf biomass alone (Frankovich 1996). The increase in epiphyte abundance (on a per short shoot basis) along this gradient was likely due to the increase in seagrass leaf substratum. In addition to epiphyte abundance on a per short shoot basis, total epiphyte loads were also greatest in western Florida Bay and were lowest within the tidally-restricted areas within central and northeastern Florida Bay.

The large differences in mean total epiphyte loads along the bird island transect were likely due to nutrient enrichment from bird defecation on Porjoe Key, a bird colony island. Eutrophication of the seagrass community causes biomass and species composition changes close to bird colonies in Florida Bay (Powell et al. 1991). The highest mean total epiphyte loads were always located at the transect point closest to the island (distance $=15 \mathrm{~m}$ ). Epiphyte loads decreased drastically between the closest point and the 2 more distally located points (Fig. 8). Differences in epiphytic species composition were also observed along this transect. Various 'fleshy' rhodophytes and chlorophytes (Chondria sp., Ceramium spp., Laurencia spp., and Derbesia $\mathrm{sp}$ ) were abundant close to the island $(15 \mathrm{~m})$. Lesser amounts of Chondria sp. were observed at the middle transect point (distance $=30 \mathrm{~m}$ ), while epiphyte composition furthest from the island $(45 \mathrm{~m})$ was dominated by animal epiphytes (especially the epiphytic bivalves Pinctada imbricata and Brachidontes exustus). Along a similar transect at Porjoe Key, Powell et al. (1991) documented an increase in seagrass biomass and a change in seagrass species composition from Thalassia testudinum to Halodule wrightii as distance decreased from the bird island. These changes in seagrass biomass and species composition are coincident with the changes in epiphyte loads and species composition of the present study. The absence of significant differences in the total epiphyte loads at 30 and $45 \mathrm{~m}$ from the island and the observed change in epiphytic species composition along the transect suggest that the effect of bird colony nutrient enrichment on epiphyte levels is pronounced but very localized, not extending even $30 \mathrm{~m}$ from the island. In contrast, seagrass stand- ing crop was enhanced up to $200 \mathrm{~m}$ from the bird island (Powell et al. 1991) and the nutrient content of the seagrass biomass showed elevated phosphorus as far as $90 \mathrm{~m}$ from the bird island (Fourqurean et al. 1992a). These findings suggest that seagrass biomass, species composition, and nutrient content are more sensitive indicators of nutrient availability than epiphyte load.

The trend of decreasing epiphyte chlorophyll loads from northwest to northeast Florida Bay and Barnes Sound was coincident with a gradual shift from algal epiphytes in western Florida Bay to animal epiphytes in the more tidally-restricted central and eastern areas of the bay (Table 1). The relative importance of algal epiphytes to the total epiphyte community, as measured by the AI, was minimum in the northeast parts of Florida Bay, and maximum in the southwest part of the bay (Fig. 7). Even though, at the time of sampling, no relationship was observed between epiphyte load and salinity or the variability thereof ( $p>0.05$ ), the salinity and the range in salinity that an individual site experiences may be a prominent factor in the epiphytic species composition at that site. The paucity of epiphytic coralline red algae and the occurrence of the epiphytic bivalves Pinctada imbricata and Brachidontes exustus in the eastern and central areas of Florida Bay is coincident with high and very often variable salinities experienced in those areas (Fig. 9; Schomer \& Drew 1982, Robblee et al. 1989, Fourqurean et al. 1993). Harlin et al. (1985) attributed the decrease in the density of epiphytic coralline red algae in the interior of Shark Bay, Western Australia, to increases in hypersalinity. In contrast, the relative abundance of the previously mentioned epiphytic molluscs in the interior of Florida Bay has been attributed to their ability to withstand 'large salinity fluctuations and other effects of poor circulation' (Turney \& Perkins 1972). Along a hypersalinity gradient in Shark Bay, the diversity and density of epiphyte species decreased significantly as levels of hypersalinity increased (Harlin et al. 1985, Kendrick et al. 1988). The standing crop of epiphytic diatoms on Halodule wrightii also decreased significantly along a hypersalinity gradient in south Texas (Jewett-Smith 1991).

Traditionally, increased epiphyte levels and elevated water column nutrient concentrations were pointed to as evidence of nutrient enrichment (Cambridge \& McComb 1984, Silberstein et al. 1986, Larkum \& West 1990, Tomasko \& Lapointe 1991), which subsequently led to declines in seagrass ecosystem health (see Duarte 1995 for review). Recent studies have shown that these traditional indicators do not fully describe nutrient availability within the ecosystem (Bulthuis et al. 1992, Neckles et al. 1993, 1994, Lin et al. 1996, Moore et al. 1996, Tomasko et al. 1996, Nelson \& Waaland 1997). Active uptake of increased nutrient loading 
Table 5. Total epiphyte loads, total dissolved inorganic nitrogen (DIN) and dissolved inorganic phosphorus (DIP) found for seagrasses at various locations. Epiphyte loads are expressed as percent of total seagrass blade + epiphyte bromass

\begin{tabular}{|c|c|c|c|c|c|}
\hline Epiphyte load & DIN $(\mu \mathrm{M})$ & $\operatorname{DIP}(\mu \mathrm{M})$ & Seagrass & Location & Source \\
\hline $5.3-43.9$ & $0.14-3.96$ & $0.03-0.43$ & Thalassia testudinum & $\begin{array}{l}\text { Florida, USA } \\
\text { Caribbean }\end{array}$ & Tomasko \& Lapointe (1991) \\
\hline $9-77$ & $43-52$ & - & Thalassia testudinum & Florida, USA & Tomasko et al. (1996) \\
\hline 1.1. & 22 & 1.73 & Zostera marina & Washington, USA & Nelson \& Waaland (1997) \\
\hline $6.5-87.5$ & $3-22$ & $0.3-1.5$ & Zostera marina & Virginia, USA & Moore et al. (1996) \\
\hline $\begin{array}{l}2.2 \cdots 61.1 \\
27.3^{\circ}\end{array}$ & $\begin{array}{c}12-22 \\
4.9^{\mathrm{d}}\end{array}$ & $\begin{array}{c}0.01-0.33 \\
0.03^{\mathrm{a}}\end{array}$ & Thalassia testudinum & Florida, USA & Present study \\
\hline
\end{tabular}

keeps water column nutrient concentrations low (Lin et al. 1996) and top-down grazer control of epiphyte or macroalgal biomass may mask any obvious effect of nutrient enrichment (Neckles et al. 1993, 1994, Williams \& Ruckelshaus 1993). Grazing pressure was found to have stronger effects on epiphyte biomass than either increases in nutrient loading (Neckles et al. 1993) or changes in leaf turnover rate (Borum 1987). It can be hypothesized that, during the time of sampling, the nutrient concentration gradient in Florida Bay (particularly that of $\mathrm{P}$ availability), though pronounced, is under the threshold for epiphyte superabundance. TIN and DIP concentrations in Florida Bay are low relative to levels measured in other seagrass ecosystems (Table 5). Phosphorus, the limiting nutrient to primary production in Florida Bay (Fourqurean et al. 1992a) and other tropical carbonate environments (Short et al. 1990), is extremely low. At the time of sampling, median DIP concentration in Florida Bay was lower or equal to that measured in other environments (Table 5), yet the total epiphyte loads measured in Florida Bay (Frankovich \& Zieman 1994, present study) span the entire range of those measured in other locations (Table 5). At the present level of epiphyte productivity, other unmeasured factors (grazing pressure, current regimes, etc.) may exert sufficient control over epiphyte accumulation. In Florida Bay, only in the immediate proximity to the bird island, a point source of nutrients, and along the northwestern boundary of Florida Bay was phosphorus availability high enough to cause increases in epiphyte levels. The uptake and storage of mutrients by seagrasses (Fourqurean et al. $1992 \mathrm{a}$, b) and their resistance to grazing pressure (Harrison 1989) make them ideal bio-indicators of ecosystem health. This study has shown that epiphyte levels are not very sensitive to moderate nutrient enrichment. Elevated water column nutrient concentrations and increased epiphyte loads are obvious but, unfortunately, may be late indicators of nutrient enrichment, and these symptoms may only become evident when seagrass ecosystems are already in decline.
Acknowledgements. The major portion of this work was supported by the South Florida Water Management District and the National Park Service, Everglades National Park under CA5280-2-9017 to R. D. Jones at Florida International University (FIU). Additional funding was supplied by grant CA5000$0-9010 / 2$ to J. C. Zieman from the National Park Service Southeast Regional Office. The authors thank R. D. Jones, Director, Southeast Environmental Research Program (SERP), FIU, and the entire SERP laboratory for supplying the water quality data. Boat support was generously provided by $D$. Smith of the Southeast Research Center of the Everglades National Park. The authors thank 3 anonymous reviewers whose comments and suggestions vastly improved the quality of the manuscript. The authors also extend a special thanks to J. C. Zieman of the University of Virginia for introducing them to the ecosystems of south Florida and enabling them to work on seagrasses in Flonda Bay. This manuscript is contribution number 58 of the Southeast Environmental Research Program, Florida International University.

\section{LITERATURE CITED}

Borum J (1985) Development of epiphytic communities on eelgrass (Zostera marina) along a nutrient gradient in a Danish estuary. Mar Biol 87:211-218

Borum J (1987) Dynamics of epiphyton on eelgrass (Zostera marina L.) leaves: relative roles of algal growth, herbivory, and substratum turnover. Limnol Oceanogr 32:986-992

Bosence D (1989) Carbonate production in Florida Bay. Bull Mar Sci 44:419-433

Bulthuis DA, Axelrad DM, Mickelson MJ (1992) Growth of the seagrass Heterozostera tasmanica limited by nitrogen in Port Phillip Bay, Australia. Mar Ecol Prog Ser 89:269-275

Bulthuis DA, Woelkerling WJ (1983) Biomass accumulation and shading effects of epiphytes on leaves of the seagrass Heterozostera tasmanica, in Victoria, Australia. Aquat Bot $16: 137-1.48$

Cambridge $\mathrm{ML}$, Chiffings $\mathrm{AW}$, Brittan $\mathrm{C}$, Moore L, McComb AJ (1986) The loss of seagrass in Cockburn Sound, Western Australia. Il. Possible causes of seagrass decline. Aquat Bot 24:269-285

Cambridge ML, McComb A.J (1984) The loss of seagrass in Cockburn Sound, Western Australia. I. The time course and magnitude of seagrass decline in relation to industrial development. Aquat Bot 20:229-243

Duarte CJ (1995) Submerged aquatic vegetation in relation to different nutrient regimes. Ophelia 41:87-112

Durako MJ (1994) Seagrass die-off in Florida Bay (USA): 
changes in shoot demographic characteristics and population dynamics in Thalassia testudinum. Mar Ecol Prog Ser 110:59-66

Fenchel $T$ (1970) Studies on the decomposition of organic matter derived from turtle grass. Thalassia testudinum. Limnol Oceanogr 15:14-20

Fourqurean JW, Jones RD, Zieman JC (1993) Processes influencing water column nutrient characteristics and phosphorus limitation of phytoplankton biomass in Florida Bay, FL, USA: inferences from spatial distributions. Estuar Coast Shelf Sci 36:295-314

Fourqurean JW, Zieman JC, Powell GVN (1992a) Phosphorus limitation of primary production in Florida Bay: evidence from C:N:P ratios of the dominant seagrass Thalassia testudinum. Limnol Oceanogr 37:162-171

Fourqurean JW, Zieman JC, Powell GVN (1992b) Relationships between porewater nutrients and seagrasses in a subtropical carbonate environment. Mar Biol 114:57-65

Frankovich TA (1996) Epiphyte production on the seagrass Thalassia testudinum. MSc thesis, University of Virginia, Charlottesville

Frankovich TA, Zieman JC (1994) Total epiphyte and epiphytic carbonate production on Thalassia testudinum across Florida Bay. Bull Mar Sci 54:679-695

Frankovich TA, Zieman JC (1995) A comparison of methods for the accurate measurement of epiphytic carbonate. Estuaries 18:279-284

Fry B, Parker PL (1979) Animal diet in Texas seagrass meadows: $\delta^{13} \mathrm{C}$ evidence for the importance of benthic plants Estuar Coast Mar Sci 8:499-509

Giesen WBJT, van Katwijk MM, den Hartog C (1990) Eelgrass condition and turbidity in the Dutch Wadden Sea Aquat Bot 37:71-85

Harlin MM (1980) Seagrass epiphytes. In: Phillips RC, McRoy $C P$ (eds) Handbook of seagrass biology: an ecosystem perspective. Garland STPM Press, New York, p 117-131

Harlin MM, Woelkerling WJ, Walker DI (1985) The effects of a hypersalinity gradient on epiphytic corallinacea (Rhodophyta) in Shark Bay, Western Australia. Phycologia 24 $389-402$

Harrison PG (1989) Detrital processing in seagrass systems: a review of factors affecting decay rates, remineralization, and detritivory. Aquat Bot 35:263-288

Heijs FML (1984) Annual biomass and production of epiphytes in three monospecific seagrass communties of Thalassia hemprichii (Ehrenb.) Aschers Aquat Bot 20: 195-218

Heijs FML (1985) Some structural and functional aspects of the epiphytic component of four seagrass species (Cymodoceoideae). Aquat Bot 23:225-247

Heijs FML (1987) Qualitative and quantitative aspects of the epiphytic component in a mixed seagrass meadow from Papua New Guinea. Aquat Bot 27:363-383

Humm HJ (1964) Epiphytes of the seagrass Thalassia testudinum, in Florida. Fla Bull Mar Sci Gulf Carib 14 306-341

Jewett-Smith J (1991) Factors influencing the standing crop of diatom epiphytes of the seagrass Halodule wrightil Aschers. in south Texas seagrass beds. Contrib Mar Sci 32:27-40

Kemp WM, Twilley RR, Stevenson JC, Boynton WR, Means JC (1983) The decline of submerged vascular plants in upper Chesapeake Bay: summary of results concerning possible causes. Mar Tech Soc J 17:78-89

Kendrick GA, Walker DI, McComb AJ (1988) Changes in distribution of macro-algal epiphytes on stems of the seagrass Amphibolis antarctica along a salinity gradient in
Shark Bay, Western Australia. Phycologia 27:201-208

Kitting CL, Fry B, Morgan MD (1984) Detection of inconspicuous epiphytic algae supporting food webs in seagrass meadows. Oecologia 62:145-149

Larkum AWD, West RJ (1990) Long-term changes of seagrass meadows in Botany Bay, Australia. Aquat Bot 37:55-70

Lin HJ, Nixon SW, Taylor DI, Granger SL, Buckley BA (1996) Responses of epiphytes on eelgrass, Zostera manna L., to separate and combined nitrogen and phosphorus enrichment. Aquat Bot 52:243-258

McRoy CP, McMillan C (1977) Production ecology and physiology of seagrasses. In: McRoy CP, Helferrich C (eds) Seagrass ecosystems: a scientifıc perspective. M Dekker, New York, p 53-87

Moore KA, Neckles HA, Orth RJ (1996) Zostera marina L (eelgrass) growth and survival along a gradient of nutnents and turbidity in the lower Chesapeake Bay. Mar Ecol Prog Ser 142:247-259

Morgan MD, Kitting CL (1984) Productivity and utilization of the seagrass Halodule wrightii and its attached epiphytes Limnol Oceanogr 29:1099-1176

Neckles HA, Koepfler ET, Haas LW, Wetzel RL, Orth RJ (1994) Dynamics of epiphytic photoautotrophs and heterotraphs in Zostera marina (eelgrass) microcosms: responses to nutrient enrichment and grazing. Estuaries 17\{3\}: $597-605$

Neckles HA, Wetzel RL, Orth RJ (1993) Relative effects of nutrient enrichment and grazing on epiphyte-macrophyte (Zostera marina L.) dynamics. Oecologia 93:285-295

Nelsen JE, Ginsburg RN (1986) Calcium carbonate production by epibionts on Thalassia in Florida Bay. J Sediment Petrol 56:622-628

Nelson TA, Waaland JR (1997) Seasonalıty of eelgrass, epiphyte, and grazer biomass and productivity in subtidal eelgrass meadows subjected to moderate tidal amplitude. Aquat Bot 56:51-74

Neundorfer JV. Kemp WM (1993) Nitrogen versus phosphorus enrichment of brackish waters: responses of the submersed plant Potamogeton perfoliatus and its associated algal community. Mar Ecol Prog Ser 94:71-82

Odum EP, de la Cruz AA (1963) Detritus as a major component of ecosystems. Bull Am Inst Biol Sci 13:39-40

Odum HT (1957) Primary production of eleven Flonda springs and a marine turtle grass community. Limnol Oceanogi 2:85-97

Orth RJ, Moore KA (1983) Chesapeake Bay: an unprecedented decline in submerged aquatic vegetation. Science 222:51-53

Patriquin D (1972) Carbonate mud production by epibionts on Thalassia: an estimate based on leaf growth rate data. J Sediment Petrol 42:687-689

Penhale PA (1977) Macrophyte-epiphyte biomass and productivity in an eelgrass (Zostera marina) L. community. J Exp Mar Biol Ecol 26:211-224

Phillips GL, Eminson D, Moss B (1978) A mechanism to account for macrophyte decline in progressively eutrophicated freshwaters. Aquat Bot 4:103-126

Phlips EJ, Badylak S (1996) Spatial variability in phytoplankton standing crop and composition in a shallow inner-shelf lagoon, Florida Bay, Florida. Bull Mar Sci 58(1):203-216

Powell GVN, Fourqurean JW, Kenworthy WJ, Zieman JC (1991) Bird colonies cause seagrass enrichment un a subtropical estuary: observational and experimental evidence. Estuar Coast Shelf Sci 32:567-579

Robblee MB, Barber R, Carlson PR, Durako MJ, Fourqurean JW, Muehlstein LK, Porter D, Yarbro LA, Zieman RT, Zieman JC (1991) Mass mortality of the tropical seagrass 
Thalassia testudinum in Florida Bay (USA). Mar Ecol Prog Ser 71:297-299

Robblee MB, Tilmant JT, Emerson J (1989) Quantitative observations on salinity. Abstract Bull Mar Sci 44:523

Schomer NS, Drew RD (1982) An ecological characterization of the lower Everglades, Florida Bay, and the Florida Keys. US Fish Wildl Serv, Office Biol Serv, Washington, DC, FWS/OBS-82/25

Short FT, Dennison WC, Capone DG (1990) Phosphoruslimited growth of the tropical seagrass Syringodium filiforme in carbonate sediment. Mar Ecol Prog Ser 62: $169-174$

Silberstein K, Chiffings AW, McComb AJ (1986) The loss of seagrass in Cockburn Sound, Western Australia. III. The effect of epiphytes on productivity of Posidonia australis Hook. F. Aquat Bot 24:355-371

Strickland JDH, Parsons TR (1972) A practical handbook of seawater analysis. Bull Fish Res Bd Can 44:179-199

Tomasko DA, Dawes CJ, Hall MO (1996) The effects of anthropogenic nutrient enrichment on turtle grass (Thalassia testudinum) in Sarasota Bay. Florida. Estuaries 19:448-456

Tomasko DA, Lapointe BE (1991) Productivity and biomass of Thalassia testudinum as related to water column nutrient

Editorial responsibility: Kenneth Heck (Contributing Editor), Dauphin Island, Alabama, USA availability and epiphyte levels: field obsetvations and experimental studies. Mar Ecol Prog Ser 75:9-16

Turney WJ, Perkins RF (1972) Molluscan distribution in Florida Bay. Sedimenta III. Comparititve Sedientology Lab, Uni Mamı

Twilley RR, Kemp WM, Staver KW, Stevenson JC, Boynton WR (1985) Nutrient enrichment of estuarine submersed vascular plant communities. 1. Algal growth and effects on production of plants and associated communities. Mar Ecol Prog Ser 23:179-191

Wetzel RL, Neckles HA (1986) A model of Zostera marina L. photosynthesis and growth: simulated effects of selected physical-chemical variables and biological interactions Aquat Bot 26:307-323

Williams SL, Ruckelshaus MH (1993) Effects of nitrogen availability and herbivory on eelgrass (Zostera marina) and epiphytes. Ecology 74:904-918

Zieman JC, Fourqurean JW, Iverson RL (1989) Distribution abundance and productivity of seagrasses in Florida Bay Bull Mar Sci 44:292-311

Zieman JC, Wetzel RG (1980) Methods and rates of productivity in seagrasses. In: Phillips RC, McRoy CP (eds) Handbook of seagrass biology. Garland STMP Press, New York. p $87-116$

Submitted: October 11, 1996; Accepted: September 18, 1997 Proofs received from author(s): November 11, 1997 